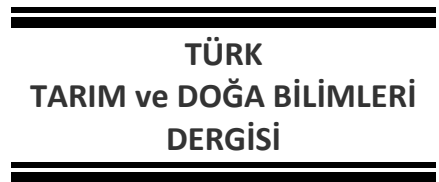

https://doi.org/10.30910/turkjans.725784

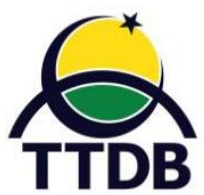

www.dergipark.gov.tr/turkjans

Araştırma Makalesi
TURKISH

JOURNAL Of AGRICULTURAL and NATURAL SCIENCES

\title{
Hatay Kent Merkezindeki Tüketicilerin Zeytinyağı Satın Alma Tercihlerini Etkileyen Faktörlerin Belirlenmesi
}

\author{
Nuran TAPKI, Bekir DEMIRTAŞ*, Erdal DAĞISTAN \\ Hatay Mustafa Kemal Üniversitesi Ziraat Fakültesi Tarım Ekonomisi Bölümü, Antakya \\ *Sorumlu yazar: bdemirtas@mku.edu.tr
}

Geliş Tarihi: 08.08.2019 Düzeltme Geliş Tarihi: 07.02.2020 Kabul Tarihi: 14.02.2020

\section{Özet}

Bu çalışmanın amacı Hatay kent merkezindeki tüketicilerin zeytinyağı satın alma davranışlarında etkili olan faktörleri belirlemektir. Araştırmanın ana materyalini 2018 yılında Hatay kent merkezinde 278 tüketici ile yapılan anketlerle elde edilen veriler oluşturmaktadır. Araştırmada cinsiyet, medeni durum, yaş, eğitim ve gelir seviyesi ile aylık gıda harcamaları dikkate alınarak zeytinyağı satın alma tercihleri ortaya konulmuştur. Katılımcıların zeytinyağı satın alma davranışlarını belirlemede, zeytinyağının faydaları ve çeşitlerine ilişkin tüketici bilgi düzeyleri, satın alma yerleri ve tüketimlerindeki değişim ile ambalaj tercihleri dikkate alınmıştır. Tüketicilerin çeşitli sosyo-ekonomik özelliklerine göre zeytinyağı satın alma tercihleri arasındaki farklılıklar kikare testi ile analiz edilmiştir. Tüketiciler zeytinyağını üreticilerden (\%62.9), marketlerden (20.1), fabrikalardan (13.3) ve şarküterilerden (3.6) satın almaktadır. Tüketicilerin \%74.5'i zeytinyağının insan sağlığına yararlarını bilmektedir ve bunların büyük çoğunluğu (\%92.4) zeytinyağını çok sağlıklı veya sağlıklı olarak nitelendirmiştir. Tüketiciler arasında eğitim seviyesi arttıkça zeytinyağı çeşit bilgisi de artış göstermektedir. Katılımcıların, zeytinyağı satın alma tercihleri ile cinsiyet, medeni durum, yaş, aylık gelir ve aylık gıda harcamaları arasındaki farklar önemli bulunmamıştır. Buna karşılık tüketicilerin eğitim seviyelerine göre ambalaj tercihleri, zeytinyağı çeşit bilgisi ve zeytinyağı satın alınan yerleri arasındaki farklar önemli bulunmuştur. Zeytinyağı üreticilerine ürün geliştirme, pazarlama ve satış artırma çalışmaları sırasında ambalaj, yeni ürün ve çeşit tanıtımı ile perakende satış yerleri konusunda tüketici tercihlerini ve eğilimlerini dikkate alması önerilebilir. Zeytin ve zeytinyağı üretimini ve tüketimini geliştirmek için önümüzdeki süreçte uygulanacak olan politikalarda tüketici tercihlerinin de dikkate alınarak yeni düzenlemelerin bunlara göre oluşturulmasında yarar vardır.

Anahtar kelimeler: Zeytinyağı, Hatay, sosyo-ekonomik yapı, tüketici tercihi, tüketici davranışı

\section{Determination of Factors Affecting Olive Oil Purchasing Preferences of Consumers in Hatay City Center}

\begin{abstract}
The aim of this study is to determine the factors that affect the olive oil buying behaviors of consumers in Hatay city center. The main material of the research is the data obtained from the surveys conducted with 278 consumers in the city center of Hatay in 2018. In this research, the preferences of purchasing olive oil were determined by considering gender, marital status, age, education and income level and monthly food expenditures. In determining the olive oil buying behaviors of the participants, consumer information levels regarding the purchase places, benefits and varieties of olive oil and change in consumption and packaging
\end{abstract}


preferences were taken into consideration. The differences between consumers' preferences to purchase olive oil according to various socio-economic characteristics were analyzed by chi-square test. Consumers buy olive oil (62.9\%) from producers, convenience stores $(20.1 \%)$, factories $(13.3 \%)$ and delicatessens $(3.6 \%)$. $74.5 \%$ of consumers know the benefits of olive oil to human health and the majority of them (92.4\%) described olive oil as very healthy or healthy. As the education level among consumer's increases, type of olive oil is also increasing. The differences between the participants' buying olive oil preferences and gender, marital status, age, monthly income and monthly food expenditure were not significant. In contrast, the differences between the packaging preferences, the knowledge of olive oil and the purchasing places of olive oil were found to be important for consumers' education levels. Olive oil producers may be advised to consider consumer preferences and trends in packaging, new product and variety promotion and retail outlets during product development, marketing and sales promotion activities. In order to improve the production and consumption of olive and olive oil, it is useful to formulate new regulations by taking consumer preferences into consideration in the policies to be implemented in the coming period.

Key words: Olive oil, Hatay province, socio-economic structure, consumer choice, consumer behavior

\section{Giriş}

Beslenme alışkanlıkları insanların yaşamlarını sağlıklı sürdürmesinde önemli boyutta etkilidir. Beslenme alışkanlıkları konusunda yapılan çalışmalarda üzerinde durulması gereken önemli bir hususta yağlardır. Günümüzde özellikle Akdeniz beslenme tarzında zeytinyağını ön plana çıkmıştır (Demirci ve Bölükbaşı, 2003; Çakmakçı ve Tahmas Kahyaoğlu, 2012). Son yıllarda Akdeniz beslenme tarzı ve içerdiği gıdalar geniş çapta araştırılmaktadır. Zeytin ve naturel zeytinyağı Akdeniz beslenme tarzı ya da diyetinin önemli bileşeni olup içerdiği birçok yararlı bileşik zeytinden zeytinyağına geçiş yapmaktadır (Wahrburg ve ark., 2002; Konuşkan ve Altan, 2007; Ryan ve ark., 2002).

Türkiye'de zeytin üretiminde Ege ve Akdeniz bölgeleri önde gelmektedir. Üretim miktarı ve üretim alanı bakımından önemli iller Aydın, Muğla ve İzmir'dir. Türkiye'nin toplam zeytin üretimi 2018 yılında 1.5 milyon tondur ancak üretim yıllar arasında verimdeki dalgalanmalara bağlı olarak 2 milyonu geçebilmektedir. Toplam zeytin üretiminin $\% 25^{\prime} \mathrm{i}$ sofralık çeşitlerden oluşurken geriye kalanı ise yağlık çeşitlerdir. Yağlık zeytin çeşitlerinin üretiminde Aydın, İzmir, Muğla, Balıkesir ve Hatay illeri başta gelmektedir. Türkiye'nin zeytinyağı üretimi 2018 yılında 200 bin ton civarındadır ancak bu rakam üretim miktarına göre dalgalanma göstermektedir. Türkiye dünya zeytinyağı üretiminde ilk 5 ülke içinde yer almaktadır. Zeytinyağı ihracatında dünyada söz sahibi ülkeler İspanya, İtalya, Tunus ve Türkiye'dir. Türkiye'nin ihracatı 2018 yılında 65 bin tonun üzerinde gerçekleşmiştir, ithalat miktarı ise çok önemsizdir (Anonim, 2018a). Hatay ili yağlık zeytin üretiminde Akdeniz bölgesinin en önemli iki ilinden biridir ve oldukça yüksek üretim potansiyeline de sahiptir. Hatay ilinin son yıllardaki zeytinyağı üretim miktarı ortalama 34,000 ton olup bölgede 75 adet zeytinyağı prese fabrikası faaliyet göstermektedir (Anonim, 2018b). Bölgede üretilen zeytinyağları rafine işlemi görmeden elde edilmekte ve doğal olarak tüketilebilen bir bitkisel yağ türüdür (Kiritsakis ve Shahidi, 2017; Konuşkan, 2017). Türkiye dünyada önemli zeytinyağı üreticisi ülkeler arasında olmasına rağmen bu ülkelere göre kişi başına zeytinyağı tüketiminin en az olduğu ülke durumundadır. Yıllık zeytinyağı tüketimi kişi başına 1.8 litre civarındadır. Hedef tüketim miktarının ise yıllık 5 litre düzeyinde olması gerekir (Anonim, 2019).

Zeytinyağının tüketimi önceki yıllarda daha çok üretildiği yerlerde yoğunlaşmıştı. Ancak tüketicilerin insan sağlığına olan faydası konusunda bilinçlenmesi ile birlikte üretim yapılmayan yerlerde de tüketim artış göstermiştir. Türkiye'de zeytinyağı tüketim miktarı ve tüketici sayısı son yıllarda önemli düzeyde artmıştır. Üretim ise Marmara, Ege, Akdeniz ve Güneydoğu Anadolu bölgelerinde yoğunlaşmıştır (Unakıtan ve ark., 2012). Zeytinyağı diğer birçok yağdan farklı olarak insanlar tarafından yan etkisi olmadan kullanılabilen bir yağ türüdür. İnsanların giderek sağlıklı ve uzun yaşama arzusu, zeytinyağına olan ilgiyi arttırmaktadır. Zeytinyağının insan sağlığına olan faydasını arttıran özelliği, ısıl işleme tabi 
olmaması ve soğuk presten geçirilerek elde edilmesidir (Özata ve Cömert, 2016; Karabulut, 2013). Zeytinyağı sağlıklı yaşamanın önemli bir kaynağıdır. Kendisine has koku, aroma ve antioksidan özelliğe sahiptir. Ayrıca birçok vitamini, flavanoidleri ve sterolleri bünyesinde barındırmaktadır. Zeytinyağı günümüzde daha çok mutfaklarda yemek yapımında, salatalarda, sağlık alanında ve vücut bakımında kullanılan bir yağdır (Ünsal, 2008; Özata ve Cömert, 2016; Küçükkömürler ve Uluksar, 2018).

Zeytinyağı tüketimi ve satın alma alışkanlıkları konusunda dünyada ve Türkiye'de çeşitli çalışmalar yapılmıştır. Yunanistan'daki tüketicilerin sosyo-ekonomik ve yerleşim yeri özelliklerine göre zeytinyağı tüketimlerinin incelendiği bir araştırmada en önemli zeytinyağı tüketim grubunun genç ve eğitimli hane halklarından oluştuğu belirlenmiştir. Aynı çalışmada zeytinyağı satın alımında zeytinyağı üreticisi olan akraba ve arkadaşların tercih edilmeye devam edildiği ve bunların payının hala önemini koruduğu ancak genç tüketicilerin organize satıcılara yöneldiği vurgulanmaktadır. Zeytinyağı tüketim miktarını etkileyen en önemli değişkenler arasında yaş, eğitim düzeyi ve yerleşim yerinde zeytin yetiştiriciliğinin yapılıyor olması gösterilmiştir (Vlontzos ve Duquenne, 2014). Brezilyalı zeytinyağı tüketicilerinin duyusal algı ve satın alma niyetlerinin araştırıldığı bir başka çalışmada satın alma niyeti ve tercihi ile ilgili olarak tüketiciler, tanımlanan duyusal yönlerden tamamen yakın olmayan karışık davranışlar sergilemişlerdir. Bu nedenle, zeytinyağı tüketicileri faydacı, naif ve uzman tüketiciler şeklinde üç gruba ayrılmıştır (Antonialli ve ark., 2018). İtalya'da zeytinyağı tüketimi konusunda yapılan bir çalışmada ise üretim yerinin zeytinyağı satın alırken tüketiciler tarafından dikkate alınan en önemli ipuçlarından biri olduğunu doğrulanmıştır. Ancak geleneksel manzarayı koruyan zeytin yetiştiriciliğinin, sadece bazı pazar segmentleri için tüketici davranışları üzerinde önemli bir etkisi olduğu görülmüştür (Tempesta ve Vecchiato, 2019). Kentsel orta gelirli tüketicilerin artmasının zeytinyağı perakende sektörü için pazar segmentlerinde oluşturduğu değişimi belirlemeye yönelik bir başka çalışmada, sonuçlar, belirli tüketicilere hitap eden yerli zeytinyağının küçük niş pazarlar için güçlü bir tercih olduğunu göstermiştir (Chan-Halbrendt ve ark., 2010). Akdeniz diyetinin ana bileşenlerinden olan zeytinyağının tüketiciler arasında benimsenmesini etkileyen faktörlerin incelendiği bir çalışmada ise zeytinyağı tüketim geleneğine sahip olan ve olmayan ülkelere göre farklı tanıtım ve benimseme çalışmalarının yapılması gerektiği ortaya konulmaktadır (Jiménez-Guerrero ve ark., 2012). Türkiye'de 7 farklı bölgede 25,764 tüketici ile yapılan bir çalışmada Türk tüketiciler arasında zeytinyağı seçimlerinde ve tüketimlerinde aile reisinin ve hane gelirinin, hane halkı büyüklüğünün, eğitim düzeyinin, hane halkı reisinin yaşının ve cinsiyetinin, çalışan eşli olmanın ve hane halkı yerleşim alanlarındaki (kırsalkentsel) bölgesel farklılıkların istatistiksel olarak anlamlı faktörler olduğu ve önemli bir rol oynadığı belirlenmiştir (Yıldız Tiryaki, 2008).

Bu çalışmada, zeytin ve zeytinyağı üretimi ve tüketimi bakımından önemli bir bölge olan Hatay ilinde, artan tüketim bilinci ve tüketim miktarına bağlı olarak tüketicilerin zeytinyağı satın alma davranışlarının ve bunu etkileyen faktörlerin belirlenmesi amaçlanmıştır. Tüketici profilinde oluşan değişimler karşısında yaş, cinsiyet, medeni durum, eğitim ve gelir durumu gibi sosyoekonomik özellikler açısından zeytinyağı satın alma yerlerinin ve ambalaj tercihlerinin nasıl değiştiğinin belirlenmesi amaçlanmıştır.

\section{Materyal ve Yöntem}

Çalışmanın ana materyalini Hatay ilinde kentsel alanda zeytinyağı tüketicileri ile yapılan anket çalışması sonucunda elde edilen birincil veriler oluşturmaktadır. Araştırma 2018 yılı sonunda Hatay ili merkez ilçelerindeki mahallelerde, halen zeytinyağı tükettiğini belirten tüketicilerle yapılmıştır. Ayrıca araştırmada konuyla ilgili olan ikincil verilerden de yararlanılmıştır. Çalışmanın amacı zeytinyağı tüketicilerinin satın alma tercihleri ve bu tercihleri etkileyen faktörlerin belirlenmesidir. Araştırmanın birinci bölümünde tüketicilerin sosyo-ekonomik özellikleri ve ikinci bölümde ise tüketicilerin satın alma davranışları üzerinde durulmuştur.

Araştırmada örnek hacmi "Anakitle Oranlarına Dayalı Basit Tesadüfi Olasılık Örneklemesi" yöntemi ile belirlenmiştir (Malhotra, 2004). Çalışmada tüketicilerin zeytinyağı tüketim durumları önceden bilinmediği için araştırmanın 
örnek hacmi, ana kitle oranlarına dayalı ve tek aşamalı basit tesadüfi olasılık örnekleme yöntemi ile belirlenmiştir

$$
\mathrm{n}=\frac{\mathrm{z}^{2}(\mathrm{pq})}{\mathrm{d}^{2}}
$$

Eşitlikteki; n: örnek sayısı, z: 1.64 (\%90 güven düzeyine karşılık gelen standart z değeri), p: incelenen konuyla ilgili önbilgi ya da tahmine dayalı olarak belirli bir özelliğe sahip anakitle oranı (0.5 olarak belirlenmiştir), q: (1-p) ilgili özelliğe sahip olmayan ana kitle oranı ve d: kabul edilen hata tolerans düzeyi $\pm \% 5$ olarak kabul edilmiştir. Çalışmada $\% 90$ güven aralığı ve $\% 5$ hata payına göre örnek hacmi 278 olarak hesaplanmıştır.

Araştırmada tüketicilerin demografik özellikleri ve satın alma davranışlarını gösteren veriler çapraz tablolar, yüzdeler, şekiller ve ki-kare test değerleri ile sunulmuştur. Ki-kare analizi, frekans dağılımları üzerinden işlem yapan bir analiz yöntemi olarak bilinmektedir. Ki-kareuygunluk testi ve ki-kare bağımsızlık testi olmak üzere iki şekilde yapılmaktadır. Değişkenler arasındaki ilişkilerin veya farklılıkların belirlenmesinde kullanılmaktadır (Altunışık ve ark., 2005; Sevimli ve Gülçubuk, 2018). Bu çalışmada incelenen konular arasındaki farklılığın önemi Kikare bağımsızlık testi ile incelenmiştir. Bu analiz yönteminde iki veya daha fazla değişken grubu arasında ilişki bulunup bulunmadığı incelenir. Yani değişkenler arasında bağımsızlık olup olmadığı araştırılmıştır.

\section{Araştırma Bulguları ve Tartışma}

\section{Tüketicilerin sosyo-ekonomik özellikleri}

Tüketicilerin \%23.4'ü kadın, \%76.6'sı erkek olup, \%44.2'si 41-50, \%29.1'i 51-60, \%12.6'sı 31-40 yaş aralığındadır. Tüketici yaş değerleri en küçük 25 , en büyük 87 olup ortama yaş 48.61 olarak hesaplanmıştır. Katılımcıların 61 yaş ve üzerindekiler ile 30 yaş ve altındakilerin oranı ise $\% 10$ 'un altındadır. Incelenen tüketiciler içinde 4 ve daha fazla aile büyüklüğüne sahip olanların oranı \%56.1 ile 1. sıradadır, 3-4 olanların oranı ise $\% 33.5$ 'tir. Ortalama aile büyüklüğü de 5 kişi olarak belirlenmiştir. Tüketicilerin \%79.5' evli olup sadece \%20.5'i bekardır. Katılımcıların \%33.5'i lise mezunu, \%45.7'si ilköğretim mezunu,\%7.2'si ise üniversite mezunudur. Tüketicilerin \%34.5'i memur, \%33.5'i serbest meslek sahibidir. Aylık geliri 3.001-6.000 TL arasında olanların oranı \%48.6 olup incelenen tüketiciler içindeki en kalabalık grubu (135 kişi) oluşturmaktadır. (Çizelge 1).

Çizelge 1.Tüketicilerin sosyo-ekonomik özellikleri ( $n=278)$

\begin{tabular}{|c|c|c|c|c|c|c|c|}
\hline Özellikler & & Sayı & $\%$ & Özellikler & & Sayı & $\%$ \\
\hline \multirow{2}{*}{ Cinsiyet } & Erkek & 65 & 23.4 & \multirow{4}{*}{ Eğitim düzeyi } & İlköğretim & 127 & 45.7 \\
\hline & Kadın & 213 & 76.6 & & Lise & 93 & 33.5 \\
\hline \multirow{5}{*}{ Yaş grupları } & 30 yaş ve altı & 16 & 5.8 & & Önlisans & 38 & 13.7 \\
\hline & $31-40$ & 35 & 12.6 & & Lisans & 20 & 7.2 \\
\hline & $41-50$ & 123 & 44.2 & \multirow{4}{*}{ Meslek grupları } & Memur & 96 & 34.5 \\
\hline & $51-60$ & 81 & 29.1 & & İşçi & 63 & 22.7 \\
\hline & 61 yaş ve üzeri & 23 & 8.3 & & Serbest meslek & 93 & 33.5 \\
\hline \multirow{3}{*}{ Aile büyüklüğü } & $1-2$ & 29 & 10.4 & & Emekli & 26 & 9.4 \\
\hline & $3-4$ & 93 & 33.5 & \multirow{4}{*}{ Gelir grupları } & 2000 TL ve altı & 15 & 5.4 \\
\hline & $4+$ & 156 & 56.1 & & $2001-3000$ & 78 & 28.1 \\
\hline & Evli & 221 & 79.5 & & $3001-6000$ & 135 & 48.6 \\
\hline Medeni durum & Bekar & 57 & 20.5 & & 6001 TL ve üzeri & 50 & 18.0 \\
\hline
\end{tabular}


Tüketicilerin zeytinyağı tüketimi ve zeytinyağı bilinci

Türkiye'de kişi başına yıllık zeytinyağı tüketiminin $1.4 \mathrm{~kg}$ kadar olduğu ve bu tüketim miktarının diğer üretici ülkelere göre oldukça düşük olduğu görülmektedir. Zeytinyağı üreticisi olan ülkelerde tüketim miktarı, özellikle $A B$ ülkelerinden Yunanistan'da 12.8 kg, İspanya'da 11.3 kg, İtalya'da 10.5 kg ve Portekiz'de 7.2 kg ile Türkiye'nin çok üzerinde gerçekleşmektedir (EU, 2019). Diğer üretici ülkelerden Tunus, Ürdün ve Lübnan'da dahi yıllık tüketim miktarı $3 \mathrm{~kg}$ civarındadır.

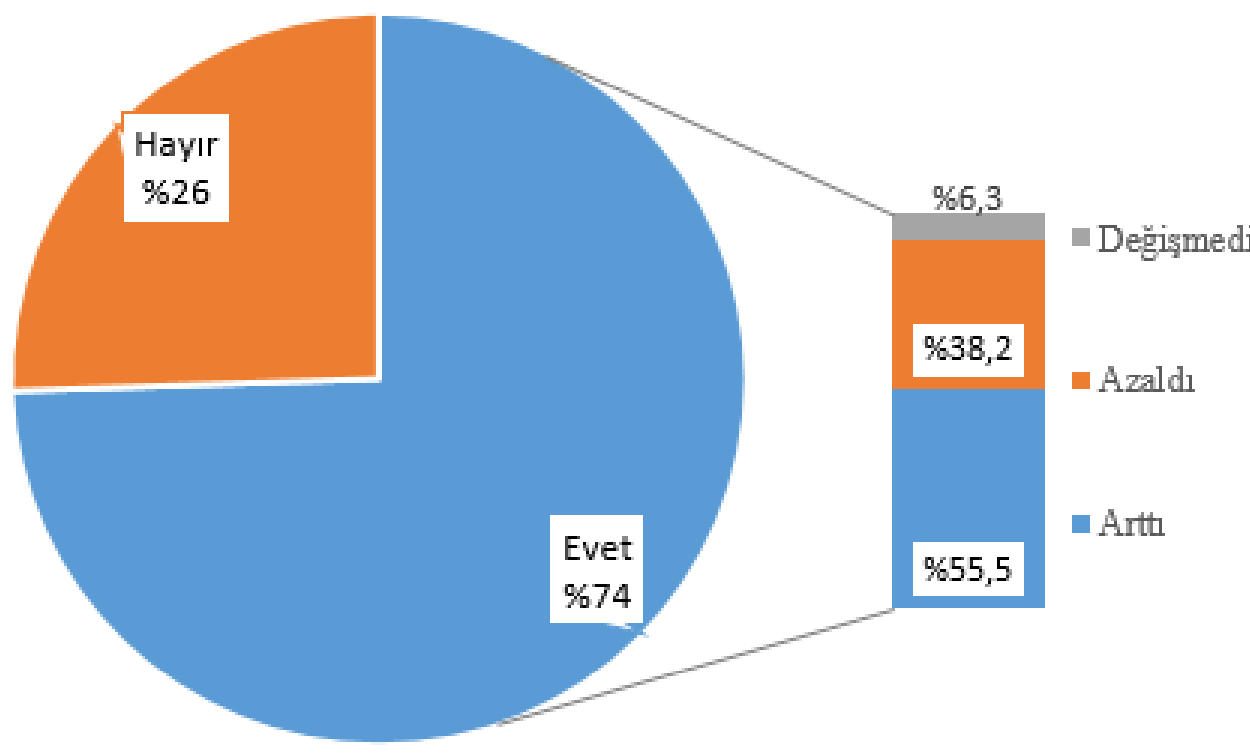

Şekil 1. Tüketicilerin zeytinyağının faydalarını bilme durumu ve tüketimlerindeki değişim

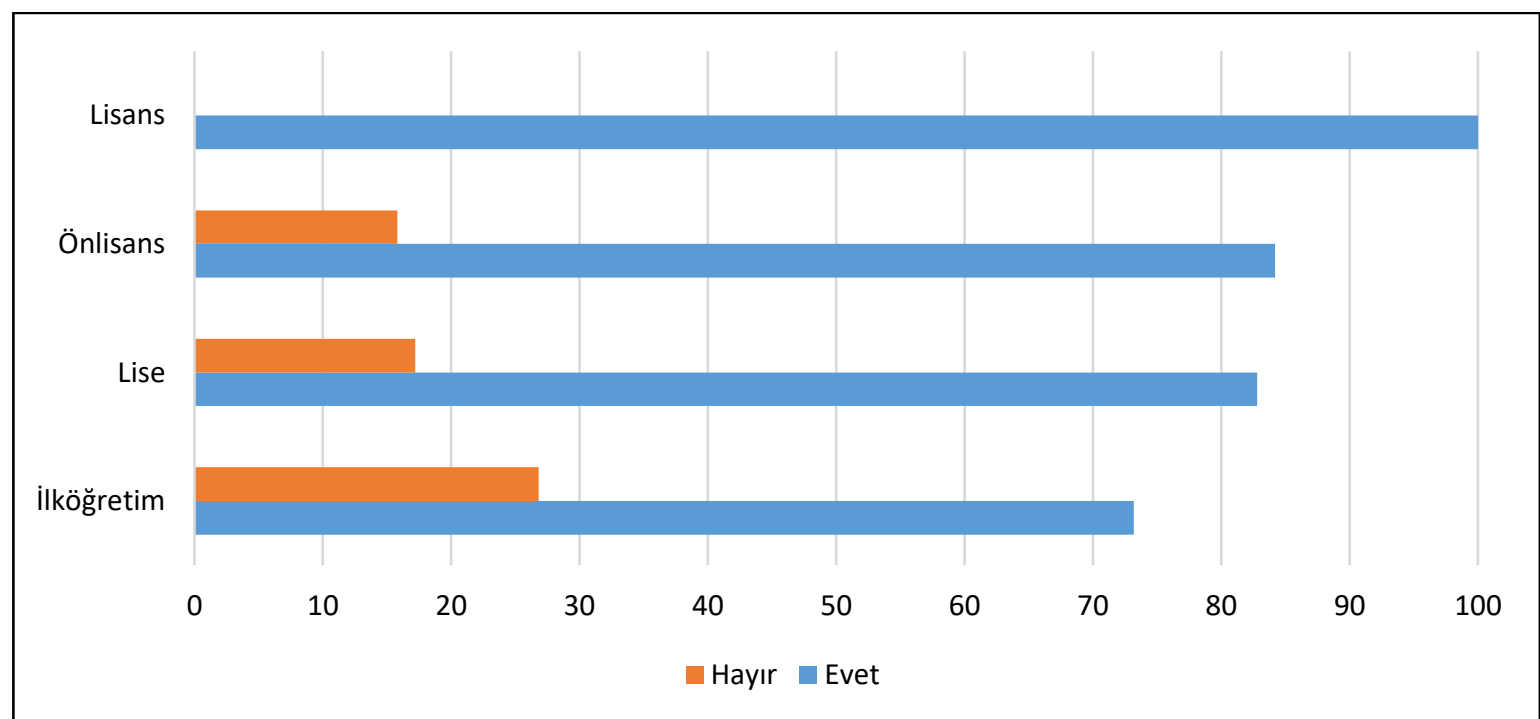

Şekil 2. Tüketicilerin eğitim düzeyi ve zeytinyağı çeşit bilgisi (\%) 
Ailelerin zeytinyağı tüketim miktarının özellikle üretim bölgelerinde diğer bölgelere göre daha fazla olması beklenir. Fiyat avantajı, kolay bulunabilme ve tüketim alışkanlıkları gibi nedenler bu durum üzerinde etkilidir. Nitekim araştırma bölgesindeki ailelerin yıllık ortalama zeytinyağı tüketimi $38.9 \mathrm{~kg}$ olarak belirlenmiştir. Bu tüketim miktarı ailelerdeki ortalama kişi sayısına göre hesaplandığında ise $7.8 \mathrm{~kg}$ civarındadır. Bu tüketim miktarı Türkiye ortalamasının 5 katına yakındır. Tüketilen zeytinyağının çeşidi ise ağırlıklı olarak natürel (\%63.2) ve rafine (\%31.6) şeklindedir. Tüketiciler zeytinyağını yemeklerde, kahvaltıda, kızartmalarda, mezelerde ve salatalarda kullanmaktadır. Tüketiciler kişi başına yıllık zeytinyağı tüketiminin \%37.5'ini çiğ olarak ve $\% 62.5^{\prime}$ ini de yemeklerde tüketmektedir. Yemeklerde tüketilen zeytinyağının ise \%31.1'i ise kızartmalarda kullanılmıştır.

Tüketicilerin zeytinyağının insan sağlığına olan faydalarını bilip bilmedikleri incelendiğinde alınan cevapların \%74.5'i (207) evet, \%25.5'i (71) ise hayır şeklindedir. Zeytinyağının sağlık faydalarının bilinmesi ve zeytinyağı tüketimindeki değişiklikler incelendiğinde, zeytinyağının sağlığa faydalarını biliyorum cevabını veren tüketicilerin \%55.6'sı tüketimlerinin arttığını, \%38.2'si değişmediğini ve \%6.3'ü de azaldığını belirtmişlerdir. Zeytinyağının insan sağlığına olan faydalarını bilmediğini ifade eden tüketicilerin, zeytinyağı tüketimlerinin \%42.3 oranında arttığı, \%52.1 oranında değişmediği ve \%5.6 oranında ise azaldığı belirlenmiştir (Şekil 1). Katılımcıların zeytinyağının insan sağlığına olan faydaları konusundaki görüşleri incelendiğinde, tüketicilerin \%46.4'ü zeytinyağını çok sağlıklı bulduğunu belirtirken, \%46'sı sağlıklı, \%6.5'i diğer yağlarla aynı ve \%1.1'i de sağlıksız bulmuştur. Ağır ve ark., (2018)'nın İzmir'de yaptıkları çalışmalarında tüketiciler zeytinyağını \%47.2 oranında sağlıklı olması nedeniyle tercih ettiklerini belirtmişlerdir. Benzer sonuç bu çalışmada da elde edilmiştir. Tüketicilerin eğitim seviyeleri ile zeytinyağının sağlığa faydası konusundaki düşünceleri incelendiğinde lisans mezunlarının \%60'ı, önlisans mezunlarının \%57.9'u, lise mezunlarının \%48.4'ü, ilköğretim mezunlarının ise \%48.0'i zeytinyağını çok sağlıklı bulmuştur. Eğitim sevileri ile zeytinyağının sağlıkla olan ilişkisi konusunda tüketicilerin benzer bir görüş ortaya koyduğu söylenebilir.

Zeytinyağları bileşimindeki asit seviyesine ve işleme tekniğine göre sızma, natürel, soğuk sıkım gibi çeşitli kategorilere ayrılmaktadır. Ankete katılan tüketicilerin hangi çeşit zeytinyağını tercih ettikleri ve bunların özelliklerini bilip bilmedikleri incelenmiştir. Eğitim seviyelerine göre zeytinyağı tercihinde üniversite mezunlarının tamamının çeşit bilgisinin olumlu olduğu görülmüştür. Bu bilgi düzeyi ilköğretim mezunlarında \%73.2, lise mezunlarında \%82.8 ve önlisans mezunlarında ise $\% 84.2$ oranında olumludur. Tüketiciler $\% 80$ oranında zeytinyağı çeşidi bilgisine sahiptir ve eğitim düzeyi arttıkça bu bilgi düzeyi de artmaktadır (Şekil 2).

\section{Tüketicilerin zeytinyağı satın alma davranışları}

Tüketicilerin çoğunluğu zeytinyağını üreticilerden (\%63.0; 175 kişi) satın almaktadır. Marketlerden satın alma (\%20.1; 56 kişi) ikinci sırada gelmekte ve zeytin işleme fabrikalarından satın alma (13.3; 37 kişi) bunu izlemektedir. En az zeytinyağı satın alma yerlerinin ise şarküteriler (\%3.6; 10 kişi) olduğu belirlenmiştir. Tüketicilerin zeytinyağı satın alma yerleri arasındaki farklılık istatistiki olarak önemli bulunmuştur $\left(\chi^{2}: 228.9\right.$; $\mathrm{p}=0.00<0.05)$.

Anket yapılan tüketicilerin cinsiyetleri ile zeytinyağını satın aldıkları yerler incelendiğinde erkek tüketicilerin en çok üreticiden (\%64.3) ve market/şarküteriden (\%23.5) zeytinyağı satın aldıkları belirlenmiştir. Kadın tüketicilerde erkek tüketiciler gibi en çok üreticilerden (\%58.5) ve market/şarküteriden (\%24.6) zeytinyağı satın almaktadır. Tüketicilerin cinsiyetleri ile ürün satın alma yerleri arasında istatistiki açıdan anlamlı bir fark bulunamamıştır ( $\left.\chi^{2}: 1.131 ; p=0.568>0.05\right)$. Unakıtan ve ark., (2012)'nın “Tekirdağ ilinde zeytinyağı tüketicileri ile yaptıkları araştırmalarında \%69.2'sinin zeytinyağı alımında marketleri, \%22'sinin ise üreticileri tercih ettiğini belirlemişlerdir. Tunalığlu ve ark., (2012)'nın Aydın ilinde yaptıkları çalışmada hanehalklarının tükettikleri zeytinyağının \%15.59'unu üreticiden, \%6.99'sını süper marketlerden satın aldıklarını, $\% 32.26$ 'sı kendi üretimlerini tüketmekte olduklarını belirlemişlerdir. Ağır ve ark., (2018)'nın çalışmalarında ise tüketicilerin zeytinyağı satın alırken \%30 oranında marketleri, \%24 oranında 
fabrikaları, \%17 oranında süper marketleri, \%14 oranında ise yerel pazarları tercih ettiklerini ortaya koymuşlardır. Hatay ilinde yapılan bu çalışmada zeytinyağı satın alımında üreticilerin daha çok tercih edilmesinin nedenleri arasında, bölgede zeytin ve zeytinyağı üretiminin yaygınlığı yanında, üretici fiyatlarının düşük olmasının ve tüketicilerin doğrudan üreticiye ulaşabilmelerinin etkili olduğu düşünülmektedir. Tüketicilerin zeytinyağı satın aldıkları yerler ile medeni durumları karşılaştırıldığında, evli tüketicilerin \%64.3'ü üreticiden, \%24.0'ü market/şarküterilerden zeytinyağını satın almaktadır. Bekar tüketiciler ise \%57.9 oranında üreticiden almayı tercih ederken \%22.8'i market/şarküterileri tercih etmektedir. Evli olanların \%11.8'i, bekarların ise \%19.3'ü fabrikaları tercih etmiştir. Tüketicilerin zeytinyağı satın aldıkları yerler ile medeni durumları arasındaki farklar istatistiki olarak önemli bulunmamıştır ( $\chi^{2}: 0.522 ; p=0.325>0.05$ ) (Çizelge 2).

Çizelge 2. Tüketicilerin cinsiyet/medeni duruma göre zeytinyağı satın alma yerleri $(n=278)$

\begin{tabular}{|c|c|c|c|c|c|}
\hline \multicolumn{2}{|c|}{ Cinsiyet/Medeni durum } & Market/Şarküteri & Üretici & Fabrika & Toplam \\
\hline \multirow{2}{*}{ Erkek } & Sayı & 50 & 137 & 26 & 213 \\
\hline & $\%$ & 23.5 & 64.3 & 12.2 & 100.0 \\
\hline \multirow{2}{*}{ Kadın } & Sayı & 16 & 38 & 11 & 65 \\
\hline & $\%$ & 24.6 & 58.5 & 16.9 & 100.0 \\
\hline \multirow{2}{*}{ Toplam } & Sayı & 66 & 175 & 37 & 278 \\
\hline & $\%$ & 23.7 & 63.0 & 13.3 & 100.0 \\
\hline \multirow{2}{*}{ Evli } & Sayı & 53 & 142 & 26 & 221 \\
\hline & $\%$ & 24.0 & 64.3 & 11.8 & 100.0 \\
\hline \multirow{2}{*}{ Bekar } & Sayı & 13 & 33 & 11 & 57 \\
\hline & $\%$ & 22.8 & 57.9 & 19.3 & 100.0 \\
\hline \multirow{2}{*}{ Toplam } & Sayı & 66 & 175 & 37 & 278 \\
\hline & $\%$ & 23.7 & 63.0 & 13.3 & 100.0 \\
\hline
\end{tabular}

Cinsiyet: $\chi^{2}: 1.131 ; p=0.568>0.05$ önemsiz, Medeni durum: $\chi^{2}: 0.522 ; p=0.325>0.05$ önemsiz.

Çizelge 3. Tüketicilerin yaş gruplarına göre zeytinyağı satın alma yerleri ( $n=278)$

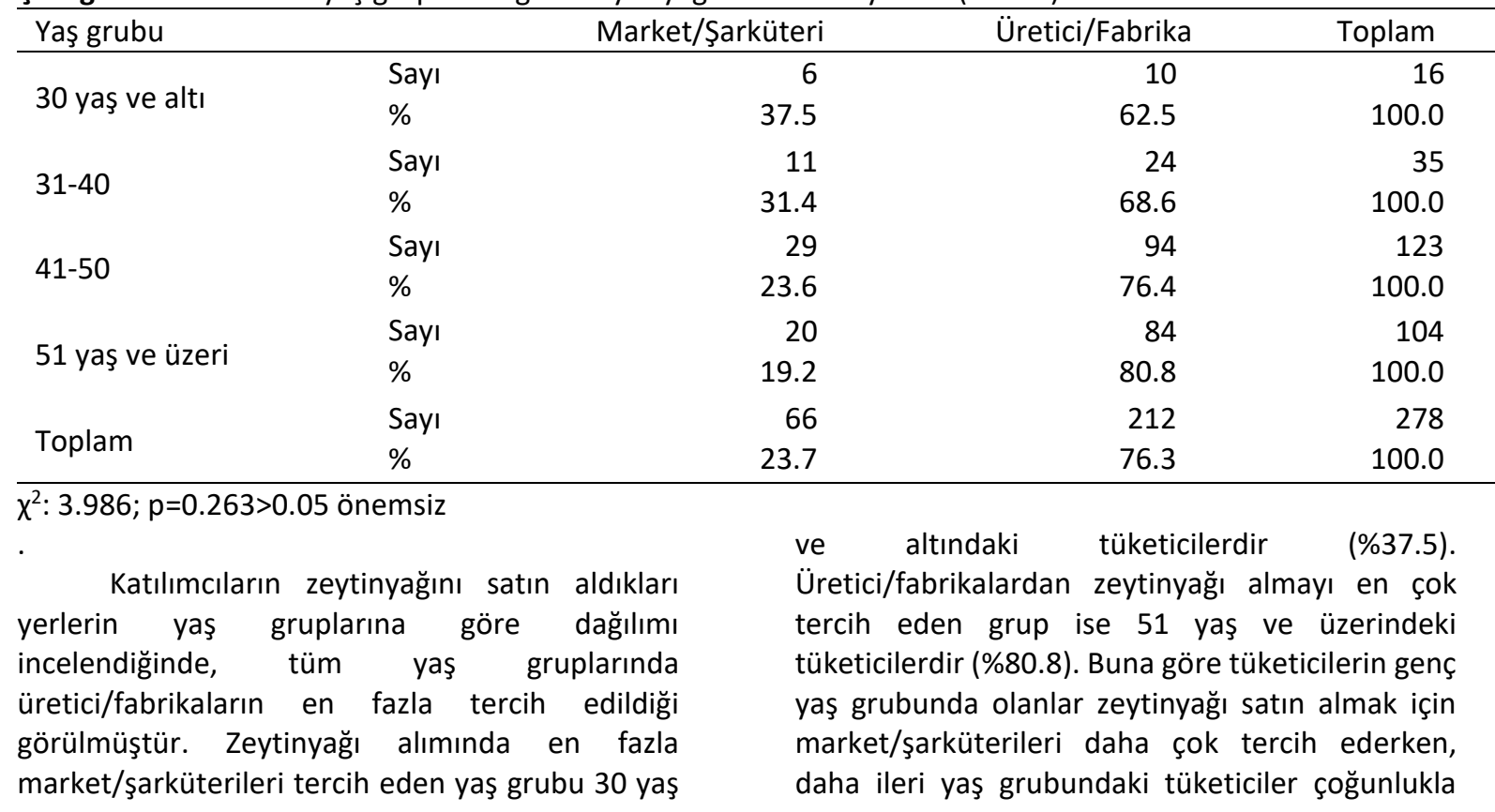


üretici/fabrikaları tercih etmektedir. Nitekim 51 yaş ve üzerindeki tüketiciler marketleri en az tercih eden yaş grubu olmuştur (\%19.2) (Çizelge 3).
Tüketicilerin zeytinyağı satın aldığı yerlerin yaş gruplarına göre gösterdiği farklılıklar istatistiki olarak önemli değildir ( $\left.\chi^{2}: 3.986 ; p=0.263>0.05\right)$.

Çizelge 4. Tüketicilerin eğitim seviyelerine göre zeytinyağı satın alma yerleri ( $n=278)$

\begin{tabular}{llccc}
\hline Eğitim düzeyi & & Market/Şarküteri & Üretici/Fabrika & Toplam \\
\hline \multirow{2}{*}{ Illköğretim } & Sayı & 11 & 116 & 127 \\
\multirow{2}{*}{ Lise } & $\%$ & 8.7 & 91.3 & 100.0 \\
\multirow{2}{*}{ Önlisans } & Sayı & 21 & 72 & 93 \\
& $\%$ & 22.6 & 77.4 & 100.0 \\
Lisans & Sayı & 23 & 15 & 38 \\
& $\%$ & 60.5 & 39.5 & 100.0 \\
Toplam & Sayı & 11 & 9 & 20 \\
& Sayı & 55.0 & 45.0 & 100.0 \\
\hline
\end{tabular}

$\chi^{2}: 55.216 ; p=0.00<0.05$ önemli.

Çizelge 5. Tüketicilerin aylık gelirine göre zeytinyağı satın alma yerleri

\begin{tabular}{llrrr}
\hline Aylık gelir (TL) & & Market/Şarküteri & Üretici/Fabrika & \multicolumn{2}{c}{ Toplam } \\
\hline \multirow{2}{*}{3.000 ve altı } & Sayı & 21 & 71.2 & 73 \\
& $\%$ & 28.8 & 109 & 100.0 \\
$3.001-5.000$ & Sayı & 25 & 81.3 & 134 \\
& $\%$ & 18.7 & 40 & 100.0 \\
5.001 ve üzeri & Sayı & 31 & 56.3 & 71 \\
& $\%$ & 43.7 & 201 & 100.0 \\
Toplam & Sayı & 77 & 73.2 & 278 \\
& $\%$ & 27.7 & 100.0 \\
\hline
\end{tabular}

$\chi^{2}: 14.547 ; p=0.00<0.05$ önemli.

Eğitim seviyesinin yükselmesiyle birlikte tüketiciler daha bilinçli hale gelmektedir. Eğitim düzeyi insanların bilgi birikimini arttırmakta ayrıca yeni bilgiler edinme isteğini kamçılamaktadır. Bilgi birikiminin artması kişilerin istek ve ihtiyaçlarını da çeşitlendirmektedir. Aynı şekilde eğitim sayesinde bilgiyi işleme etkinliği de artmaktadır (Penpece, 2006; Sevimli ve Gülçubuk, 2018). Bu çalışmadaki tüketicilerin eğitim seviyelerine göre zeytinyağını satın aldıkları yerler Çizelge 4'te verilmiştir. Lisans mezunu tüketicilerin $\% 55^{\prime} i$ zeytinyağını market/şarküterilerden satın alırken, diğerleri doğrudan üretici/fabrikalardan almaktadır. Illköğretim mezunlarında market/şarküteri tercihi \%8.7, lise mezunlarında \%22.6 ve önlisans mezunlarında ise \%60.5 olarak belirlenmiştir. Tüketicilerin eğitim seviyesi yükseldikçe zeytinyağı satın almada market/şarküteri tercihleri artış göstermektedir. Market/şarküterilerin eğitimli tüketiciler arasında kalite, ambalaj ve marka etkisiyle diğer satış yerlerine göre öne çıkmış olduğu söylenebilir. Tüketicilerin zeytinyağı satın alma yerleri ile eğitim seviyeleri arasında farklar istatistiki olarak önemlidir $\left(\chi^{2}:\right.$ 55.216; $\mathrm{p}=0.00<0.05$ ).

Zeytinyağına olan talep artarken üretim miktarı da aynı doğrultuda artmalıdır. Sektörün gelişimi yeni işleme tesislerinin kurulması, modernizasyonu, kapasite kullanım oranının artması ile mümkün olmaktadır. Artan talep, üretimin daha kaliteli ve verimli olmasını gerektirmektedir. Son yıllarda bu alanda yatırımlarında yapıldığı bilinmektedir (Seçer ve Emeksiz, 2012). Tüketicilerin aylık gelirleri ile zeytinyağı satın aldıkları yerler incelendiğinde tüm gelir gruplarında üretici/fabrikalar en yüksek orana sahiptir (ortalama \%73.2). Ancak üst gelir düzeyinde market/şarküteriden satın alınma oranı yükselmektedir (Çizelge 5). Tüketicilerin aylık gelirleri ile zeytinyağı satın alma yerleri arasındaki 
farklar istatistiki olarak önemli bulunmuştur $\left(\chi^{2}\right.$ : 14.547; $p=0.00<0.05$ ).

Tüketicilerin aylık gıda harcamaları ile zeytinyağı satın alma yerleri Çizelge $6^{\prime}$ da verilmiştir. Tüketicilerin aylık gıda harcamaları yükseldikçe üretici/fabrikadan zeytinyağı alımı oransal olarak azalmakta, buna karşılık market/şarküteriden satın alma oranı yükselmektedir. Ancak genel ortalamalara göre üretici/fabrikalar açık ara ile (\%76.3) tercih edilen satış yerleri olmuştur. Tüketicilerin aylık gıda harcamaları ile zeytinyağı satın alma yerleri arasındaki farklılıklar istatistiki olarak önemli bulunmuştur ( $\left.\chi^{2}: 13.086 ; p=0.00<0.05\right)$.

Çizelge 6. Tüketicilerin gıda harcamasına göre zeytinyağı satın alma yerleri

\begin{tabular}{llrrr}
\hline Gıda harcaması (TL) & & Market/Şarküteri & Üretici/Fabrika & \multicolumn{1}{c}{ Toplam } \\
\hline \multirow{2}{*}{1500 ve altı } & Sayı & 12 & 90 & 102 \\
& $\%$ & 11.8 & 88.2 & 100.0 \\
\multirow{3}{*}{$1.501-3.000$} & Sayı & 46 & 100 & 146 \\
\multirow{3}{*}{3.001 ve üzeri } & $\%$ & 31.5 & 68.5 & 100.0 \\
& Sayı & 8 & 22 & 30 \\
\multirow{2}{*}{ Toplam } & $\%$ & 26.7 & 73.3 & 100.0 \\
& Sayı & 66 & 212 & 278 \\
& \% & 23.7 & 76.3 & 100.0 \\
\hline
\end{tabular}

$\chi^{2}: 13.086 ; p=0.00<0.05$ önemli.

Çizelge 7. Tüketicilerin eğitim düzeyleri ile zeytinyağı ambalaj tercihleri ( $n=278$ )

\begin{tabular}{llrrrr}
\hline Eğitim düzeyi & & Teneke & Plastik ve Diğ. & Cam kavanoz & Toplam \\
\hline \multirow{2}{*}{ Illköğretim } & Sayı & 40 & 73 & 14 & 127 \\
& $\%$ & 31.5 & 57.5 & 11.0 & 100.0 \\
Lise & Sayı & 50 & 29 & 14 & 93 \\
\multirow{2}{*}{ Önlisans ve Lisans } & $\%$ & 53.8 & 31.1 & 15.1 & 100.0 \\
& Sayı & 36 & 15 & 7 & 58 \\
Toplam & $\%$ & 62.1 & 117 & 12.1 & 100.0 \\
& Sayı & 126 & 42.1 & 12.6 & 278 \\
\hline
\end{tabular}

$\chi^{2}: 24.522 ; p=0.00<0.05$ önemli.

\section{Tüketicilerin zeytinyağı ambalaj tercihleri}

Gıda ürünlerinde kullanılan ambalajların görünüm ve albeni, ürünü koruma, gramaj ayarlama gibi işlevleri vardır. Ankete katılan tüketicilerin eğitim seviyeleri ve zeytinyağ ambalaj tercihleri arasındaki dağılım Çizelge 7'de verilmiştir. Çizelgeye göre tüketiciler en çok teneke ambalajlı zeytinyağlarını tercih etmektedirler. Ön lisans ve lisans mezunlarının $\% 62$ 'si, lise mezunlarının \%53.8'i ve ilköğretim mezunlarının da \%31.5'i teneke ambalajlı zeytinyağını tercih etmiştir. Ikinci sırada tercih edilen zeytinyağı ambalajı ise plastik kaplardır. ilköğretim mezunları arasında plastik ambalajlar en fazla tercih edilmiştir (\%53.5). Tüketicilerin eğitim düzeyleri ile zeytinyağı ambalaj tercihleri arasındaki farklar istatistiki olarak önemli bulunmuştur $\left(\chi^{2}: 24.522 ; p=0.00<0.05\right)$.

\section{Sonuç ve Öneriler}

Türkiye dünyada zeytin ve zeytinyağı üretimi ve dış ticaretinde önemli bir konumda olmasına rağmen zeytinyağının iç tüketimi son derece düşüktür. Tüketim neredeyse üretim bölgelerindeki alışkanlık ile sınırlı kalmıştır. Son yıllarda tüketimin arttırılmasına yönelik girişimler sonucunda, zeytinyağı tüketiminde artış eğilimi bulunduğu görülmektedir. Ancak bu artış zeytinyağı tüketim sorununun çözüldüğü anlamına gelmemektedir. Hatay ili zeytin ve zeytinyağı üretiminde önemli bir il olması yanında tüketimde de öncelikli konumdadır.

Tüketicilerin zeytinyağı kullanımı ve bilinci konusundaki gelişmeler karşısında satın alma 
alışkanlıklarının nasıl değişme gösterdiğinin belirlenmesine yönelik olan bu araştırmada, çeşitli sosyo-ekonomik ve demografik değişkenlerle çalışma gerçekleştirilmiştir. Elde edilen başlıca sonuçlar arasında; tüketicilerin \%92.4'ü zeytinyağını çok sağlıklı veya sağlıklı bulmuştur. Hatay ilinde zeytinyağının diğer yağlara göre daha çok tercih edilme nedenleri arasında, bölgede yağ üretiminin fazla olmasından dolayı tüketicilerin diğer bölgelere göre daha ucuza bu yağı elde edebilmesi, ayrıca giderek yaygınlaşan sağlıklı yaşam bilinci artışı gelmektedir. Cinsiyet ve medeni durum bakımından tüketicilerin zeytinyağı satın alma yerleri arasında üretici/fabrikalar en fazla tercih edilen yerler olmuştur. Tüketicilerin aylık gelir ve gıda harcamalarındaki artışla marketlerden ambalajlı ve markalı zeytinyağı satın alımı artış göstermektedir. Zeytinyağı tüketiminde çeşitli ambalajlar tercih edilmektedir. Bunlar içinde en çok teneke ambalaj tercih edilmekte ve bunu plastik kaplar ve cam kavanozlar takip etmektedir. Tüketicilerin bilinçlenmesi ve gelir artışlarına bağlı olarak zeytinyağı tüketiminde miktar olarak ve markalı, ambalajlı şekilde satın almanın artmakta olduğu söylenebilir. Elde edilen sonuçlara göre üretici firmaların ve fabrikaların tüketici tercihlerine yönelik satış geliştirme çalışmalarına gitmeleri önerilebilir.

Sonuç olarak insan sağlığına en faydalı bitkisel yağlardan olan zeytinyağının üretim ve tüketiminin arttırılması için iç tüketimi artırmaya yönelik çalışmaların yanında üretimde kalite ve verimi artırmaya yönelik düzenlemelere ihtiyaç vardır. Zeytin üreticilerine yönelik uygulanan teşvik ve destekler yeterli ve sürekli olarak uygulanmalıdır. Bu uygulamalar fiyat istikrarına ve üretim bölgeleri dışındaki tüketicilerinde zeytinyağını satın almasına katkı yapacaktır. Zeytinyağı ile ilgili geliştirilecek olan yeni politikalarda toplumun satın alma tercihleri de incelenerek yeni politikaların buna göre geliştirilmesinde fayda vardır.

\section{Kaynaklar}

Ağır, M., Boran, C., Özden, F. ve Artukoğlu, M.M. 2018. Zeytinyağında tüketici tercihleri üzerine bir araştırma: İzmir ili Dikili ilçesi örneği. Ege Üniversitesi Ziraat Fakültesi Dergisi, 55(4): 441-451.
Altunışık, R., Çoşkun, R. ve Yıldırım, E. 2005. Sosyal Bilimlerde Araştırma Yöntemleri: SPSS Uygulamalı. (4. Baskı) Sakarya Kitabevi, Sakarya, 365s.

Antonialli, F., Mesquita, D.L., Valadares, G.C., Rezende, D.C. ve Oliveira, A.F. 2018. Olive oil consumption: a preliminary study on Brazilian consumers. British Food Journal, 120(7): 1412-1429.

Anonim. 2018a. Tarım Ürünleri Piyasaları. Tarımsal Ekonomi ve Politika Geliştirme Enstitüsü. https://arastirma.tarimorman.gov.tr/tepg e/Menu/27/Tarim-Urunleri-Piyasalari (Erişim Tarihi: 13.06.2019).

Anonim. 2018b. Hatay ili Ekonomik Görünüm Raporu. Doğu Akdeniz Kalkınma Ajansı, http://www.dogaka.gov.tr/Icerik/Dosya/w ww.dogaka.gov.tr_653_CG8B85TB_Hatayili-Ekonomik-Gorunum-Raporu.pdf (Erişim Tarihi: 13.06.2019).

Anonim. 2019. Zeytin Tarımı. Tarım TV. https://www.tarimtv.gov.tr (Erişim Tarihi: 13.06.2019).

Chan-Halbrendt, C., Zhllima, E., Sisior, G., Imami, D. ve Leonett, L. 2010. Consumer preferences for oive oil in Tirana, Albania. International Food and Agribusiness Management Review, (13): 3, 55-74.

Çakmakçı, S. ve Kahyaoğlu, T.D. 2012. Yağ asitlerinin sağlık ve beslenme üzerine etkileri. Türk Bilimsel Derlemeler Dergisi, 5(2): 133-137.

Demirci, M. ve Bölükbaşı, B. 2003. Akdeniz beslenme tarzında zeytinyağının önemi. Türkiye I. Zeytinyağı ve Sofralık Zeytin Sempozyumu, 2-3 Ekim, İzmir, 41-48.

EU. 2019. Economic Analysis of the EU Olive Oil Sector. (https://www.oliveoilmarket.eu co) (Erişim Tarihi: 02.01.2020).

Jiménez-Guerrero, J.F., Gázquez-Abad, J.C., Mondéjar-Jiménez, J.A. ve Huertas-García, R. 2012. Consumer preferences for olive-oil attributes: A review of the empirical literature using a conjoint approach. Olive Oil - Constituents, Quality, Health Properties and Bioconversions, Boskou Dimitrios, IntechOpen, Doi: $10.5772 / 30390$.

Karabulut, C. 2013. 2013 Yılı Zeytin ve Zeytinyağı Raporu. Aydın Ticaret Borsası, 
https://aydinticaretborsasi.org.tr/yonetim /pdf/16112016161329u.pdf (Erişim Tarihi: 10.06.2019).

Konuşkan, D., Altan, A. 2007. Zeytin ve zeytinyağında doğal olarak bulunan biyoaktif bileşikler ve fizyolojik etkileri. 2 . International Congress on Food and Nutrition, 24-26 Ekim, İstanbul.

Konuşkan, D.B. 2017. Hatay zeytinyağlarının yağ asidi ve sterol kompozisyonlar. Türk TarımGıda Bilim ve Teknoloji Dergisi, 5(2): 170175.

Kritsakis, A. ve Shahidi, F. 2017. Olives and Olive Oil as Functional Foods: Bioactivity, Chemistry and Processing. John Wiley \& Sons, Inc., 111 River Street, Hoboken, NJ, USA, 669s.

Küçükkömürler, S. ve Uluksar, F.Ö. 2018. Türk mutfak kültüründe zeytinyağı kullanımı: Muğla örneği. Journal of Turism and Gastronomy Studies, 6(2): 194-212.

Malhotra, N.K. 2004. Marketing Research (An Applied Orientation). Pearson Prentice. Fourth edition. 173s.

Özata, E. ve Cömert, M. 2016. Zeytinyağı ve sağlıklı yaşam. Zeytin Bilimi, 6(2): 105-110.

Penpece, D. 2006. Tüketici Davranışlarını Belirleyen Etmenler: Kültürün Tüketici Davranışları Üzerine Etkileri. Sütçü İmam Üniversitesi S.B.E, Yüksek Lisans Tezi, Kahramanmaraş, 155s.

Ryan, D., Antolovich, M., Prenzler, P., Robards, K. ve Shimon, L. 2002. Biotransformations of Phenolic compounds in Olea Europaea. Scentia Horticulturae, 92: 147-176.

Seçer, A. ve Emeksiz, F. 2012. Doğu Akdeniz Bölgesinde Zeytin ve Zeytinyağı Üretimi ve Pazarlaması ve Bölgede Zeytinciliği
Geliştirme Olanakları. Çukurova Üniversitesi Fen Bilimleri Enstitüsü, Doktora Tezi, Adana, 257s.

Sevimli, L. ve Gülçubuk, B. 2018. Kırmızı et ve ürünlerinde tüketicilerin satın alma tercihlerinde etkili olan faktörler. Tarım Ekonomisi Araştırmaları Dergisi, 4(2): 2533.

Tempesta, T. ve Vecchiato, D. 2019. Analysis of the factors that influence olive oil demand in the Veneto region (Italy). Agriculture, 9, 154; doi:10.3390/agriculture9070154.

Tunalıoğlu, R., Cankurt, M., Çobanoğlu, F. ve Armağan, G. 2012. Zeytinyağı tüketici davranışları. 10. Ulusal Tarım Ekonomisi Kongresi, 5-7 Eylül, Konya, 853-862.

Unakıtan, G., Başaran, B. ve Yılmaz, F. 2012. Tekirdağ ilinde zeytinyağı tüketim tercihlerinin analizi. 10. Ulusal Tarım Ekonomisi Kongresi, 5-7 Eylül, Konya, 956963.

Ünsal, A. 2008. Ölmez Ağacın Peşinde: Türkiye'de Zeytin ve Zeytinyağı. Yapı Kredi Yayınları, İstanbul, 296s.

Wahrburg, U., Kratz, M. ve Cullen, P. 2002. Mediterranean diet, Olive oil and health. European Journal of Lipid Science and Technology, 104: 698-705.

Vlontzos, G. ve Duquenne, M.N. 2014. Assess the impact of subjective norms of consumers' behaviour in the Greek olive oil market. Journal of Retailing and Consumer Services, 21: 148-157.

Yıldız Tiryaki, G. 2008. Household's olive oil consumption preferences socioeconomic and demographic differences. AgroFOOD Industry Hi-tech. (19): 5, 30-33. 